\title{
SOME ASPECTS OF THE BREEDING OF THE WHITE-WINGED SCOTER AT MIQUELON LAKE, ALBERTA
}

by Kees Vermeer, Canadian Wildlife Service, 10015-103 Avenue, Edmonton

During a study on the breeding biology of the California Gull (Larus californicus) and the Ring-billed Gull (Larus delawarensis) on two islands in Miquelon Lake, Alberta $\left(53^{\circ} 15^{\prime}\right.$ $\mathrm{N}$ and $\left.112^{\circ} 55^{\prime} \mathrm{W}\right)$, data were collected from White-winged Scoters (Melanitta deglandi) nesting among these gulls. Figure 1 shows the date of the first egg laid in 20 nests in 1964 and 1965. Most of the clutches were found during the laying period. A few which had been completed werc back-dated from the time of hatching to obtain the date of clutch initiation. The calculation in back-dating was based on one known incubation period of 25 days for this species at Miquelor

WHITE - WINGED SCOTER

1964

1965

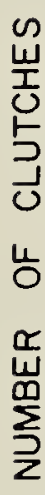
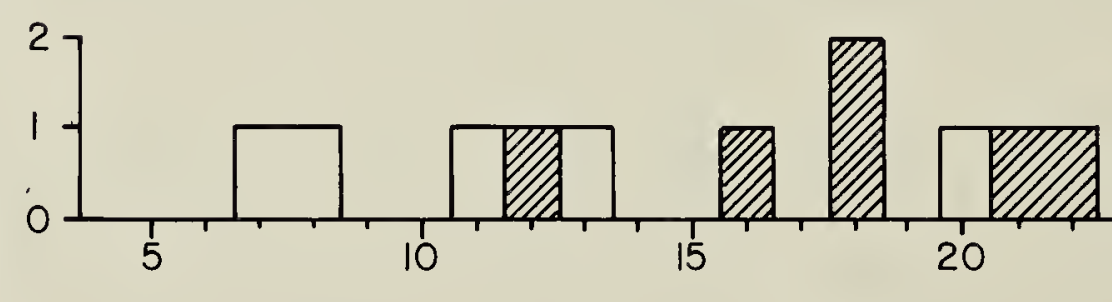

JUNE

JULY

Fig. 1 Distribution of clutch initiation of White-winged Scoters at Miquelor Lake in 1964 and 1965.

Table 1. Calculation of average egg laying interval in White-winged Scoter: at Miquelon Lake

Time interval between visits

to nests

in days

Number of visits
Total increase is number of eggs

\begin{tabular}{rrrr}
\hline 1 & 6 & 6 & 4 \\
2 & 4 & 8 & 5 \\
3 & 1 & 3 & 2 \\
4 & 3 & 12 & 7 \\
\hline Total & & 29 & 18
\end{tabular}

Average number of days per egg laid: $29 / 18=1.6$ days 
Table 2. Distribution in length and width of the eggs of White-winged Scoters compared to those of other duck species breeding at Miquelon Lake in 1964 and 1965

\begin{tabular}{|c|c|c|c|c|c|}
\hline \multirow{2}{*}{$\begin{array}{l}\text { Length in } \\
\mathrm{mm} \text {. }\end{array}$} & \multicolumn{5}{|c|}{ No. of eggs } \\
\hline & $\begin{array}{c}\text { White-winged } \\
\text { Scoter }\end{array}$ & Mallard & $\begin{array}{l}\text { Lesser } \\
\text { Scaup }\end{array}$ & Gadwall & Pintail \\
\hline $73.9-72.0$ & 1 & $\ldots$ & $\ldots$ & ... & $\ldots$ \\
\hline $71.9-70.0$ & 16 & $\ldots$ & $\ldots$ & $\ldots$ & $\ldots$ \\
\hline $69.9-68.0$ & 19 & ... & $\ldots$ & $\ldots$ & $\ldots$ \\
\hline $67.9-66.0$ & 37 & .... & $\ldots$ & $\ldots$ & $\ldots$ \\
\hline $65.9-64.0$ & 24 & & "r & $\ldots$ & $\ldots$ \\
\hline $63.9-62.0$ & 3 & 5 & 2 & $\ldots$ & $\ldots$ \\
\hline $61.9-60.0$ & & 10 & 9 & & $\ldots$ \\
\hline $59.9-58.0$ & $\ldots$ & 20 & 30 & 2 & \\
\hline $57.9-56.0$ & $\ldots$ & 31 & 43 & 14 & 7 \\
\hline $5.9-54.0$ & $\ldots$ & 21 & 15 & 38 & 15 \\
\hline $53.9-52.0$ & $\ldots$ & 13 & 1 & 32 & 39 \\
\hline $51.9-50.0$ & $\ldots$ & $\cdots$ & $\cdots$ & 14 & 33 \\
\hline $19.9-48.0$ & & & & & 6 \\
\hline Total & 100 & 100 & 100 & 100 & 100 \\
\hline Mean in $\mathrm{mm}$. & 67.33 & 56.99 & 57.55 & 53.99 & 52.70 \\
\hline \multirow[b]{2}{*}{$\begin{array}{c}\text { Width in } \\
\text { mm. }\end{array}$} & \multicolumn{5}{|c|}{ No. of eggs } \\
\hline & $\begin{array}{l}\text { White-winged } \\
\text { Scoter }\end{array}$ & Mallard & $\begin{array}{l}\text { Lesser } \\
\text { Scaup }\end{array}$ & Gadwall & Pintail \\
\hline $\begin{array}{l}49.9-48.0 \\
47.9-46.0\end{array}$ & $\begin{array}{c}9 \\
59\end{array}$ & $\cdots$ & .... & ... & $\ldots$. \\
\hline $45.9-44.0$ & 32 & 7 & $\cdots$ & $\cdots$ & $\cdots$ \\
\hline $43.9-42.0$ & & 25 & 7 & & \\
\hline $41.9-40.0$ & $\ldots$ & 51 & 44 & 3 & 3 \\
\hline $39.9-38.0$ & $\ldots$ & 17 & 47 & 86 & 39 \\
\hline $37.9-36.0$ & ... & ... & 2 & 11 & 50 \\
\hline $35.9-34.0$ & $\ldots$ & ... & $\cdots$ & $\ldots$ & 8 \\
\hline Total & 100 & 100 & 100 & 100 & 100 \\
\hline Mean in $\mathrm{mm}$. & 46.33 & 41.36 & 40.01 & 38.60 & 37.64 \\
\hline
\end{tabular}

Lake. The first White-winged Scoters were observed to arrive at Miquelon Lake on May 6, 1965. Since the first egg was laid on June 11 in that year, the pre-egg period, which is the time between first arrival of the birds on the breeding ground and the date of the first egg laid, was 36 days.

All the observed nests of the Whitewinged Scoters were situated in dense herbaceous cover. From observation on egg laying intervals the average laying interval appeared to be 1.6 days (Table 1). The eggs of the
White-winged Scoters were considerably larger than those of four other duck species found at Miquelon Lake (Table 2).

The clutch size in 12 nests of the White-winged Scoter in 1964 and 1965 ranged from 6 to 16 with an average of 10.2 eggs per nest. Of 10 clutches of known fate, five hatched, four were destroyed by predators, and one was deserted. The five clutches which hatched contained a total of 50 eggs, of which 38 hatched, 10 failed to hatch, and two disappeared. 